\title{
Iron fertilization and the structure of planktonic communities in high nutrient regions of the Southern Ocean
}

\section{Bernard Quéguiner}

Aix-Marseille Université, Mediterranean Institute of Oceanography (MIO), 13288, Marseille, cedex 09, France ; CNRS/INSU, MIO UMR 7294; IRD, MIO UMR 235.

This ms. has been published in Deep Sea Research Part II Topical Studies in Oceanography, Volume 90, June 2013, Pages 43-54; DOI:10.1016/j.dsr2.2012.07.024

\section{Abstract}

In this review article, plankton community structure observations are analyzed both for artificial iron fertilization experiments and also for experiments dedicated to the study of naturally iron-fertilized systems in the Atlantic, Indian and Pacific sectors of the Southern Ocean in the POOZ (Permanently Open Ocean Zone) and the PFZ (Polar Frontal Zone). Observations made in natural systems are combined with those from artificially perturbed systems, in order to evaluate the seasonal evolution of pelagic communities, taking into account controlling factors related to the life cycles and the ecophysiology of dominant organisms. The analysis considers several types of planktonic communities, including both autotrophs and heterotrophs. These communities are spatially segregated owing to different life strategies. A conceptual general scheme is proposed to account for these observations and their variability, regardless of experiment type. Diatoms can be separated into 2 groups: Group 1 has slightly silicified fast growing cells that are homogeneously distributed in the surface mixed layer, and Group 2 has strongly silicified slowly growing cells within discrete layers. During the growth season, Group 1 diatoms show a typical seasonal succession of dominant species, within time windows of development that are conditioned by physical factors (light and temperature) as well as endogenous specific rhythms (internal clock), and biomass accumulation is controlled by the availability of nutrients. Group 1 diatoms are not directly grazed by mesozooplankton which is fed by protozooplankton, linking the microbial food web to higher trophic levels. Instead, successive dominant species of Group 1 are degraded via bacterial activity at the end of their growth season. Organic detritus fragments feed protozooplankton and mesozooplankton. The effective silicon pump leads to the progressive disappearance of silicic acid in surface waters. In contrast, Group 2 is resistant to grazing due to its strong silicification, and its biomass accumulates continuously but relatively slowly throughout the productive period. Group 2 
diatoms are concentrated at or near the seasonal pycnocline and thus benefit from upward nutrient fluxes by diapycnal mixing. The decrease in light and the deep convective mixing in the fall produce both light and nutrient limitation leading to a massive carbon export of Group 2 diatoms, a major annual event of the biological pump. This scheme describes the seasonal evolution of plankton communities in surface waters of the Southern Ocean. The scheme could probably be extended to ecosystems that are characterized by a seasonal bloom under influence of iron or other nutrients.

Keywords: Plankton, Community composition, Trophic relationships, Southern Ocean, Limiting factors, Iron, Life cycle.

Corresponding author. Tel.: +33491829105; fax :+33491821991.

E-mail address: bernard.queguiner@univ-amu.fr(B. Quéguiner).

\section{Introduction}

Since the mid 1990's many in situ experiments have been conducted in different parts of the oceans in order to better understand effects of iron fertilization on pelagic ecosystem structures and the efficiency of organic carbon export at depth (i.e. beyond the surface mixed layer). The first experiments of mesoscale artificial fertilization generated enthusiasm by showing unambiguously that iron plays a limiting role in high nutrient low chlorophyll (HNLC) areas (Martin et al., 1994; Coale et al., 1996). These results have progressively given way to skepticism about their representativeness and their applicability to full-scale natural ecosystems (Boyd et al., 2007). A key source of doubt is the fact that recurrent observations show no significant increase in vertical flux of particulate organic carbon (POC) which could hypothetically be related to the artificial additions of iron to surface waters. It is within this context that a holistic approach to questions on iron fertilization has emerged in areas of the world ocean where HNLC waters are enriched with natural iron. This new approach also reveals a difference between artificial and natural iron fertilization systems: systems that are naturally enriched with iron have developed, on long (geological?) time scales, as a natural adaptation in the form of specific pelagic communities, while artifically disturbed systems have responded only on short time scales (Boyd et al., 2007).

The biological carbon pump is a fast process which has played an important role in regulating atmospheric $\mathrm{CO}_{2}$, and in turn climate (Bishop and Wood, 2009). Robinson et al. (2010) defines the biological pump as "the reprocessing and downward advection of dissolved organic matter, the sinking flux of particulate matter, and the active transport of organic matter and associated biominerals via vertical migration." This definition underscores the unique role of pelagic plankton communities from bacteria to mesozooplankton. In these communities primary production, biotic processing or repackaging of POC, differential regeneration of major elements and zooplankton 
vertical migration are primarily responsible for setting the export carbon flux out of the euphotic zone and controlling the magnitude and efficiency of carbon export that varies as a function of depth, season, and regional ecosystem structure (Buesseler and Boyd, 2009). In particular, the structure of a pelagic community determines the strength of its biological pump, defined as the magnitude of biogenic matter escaping the epipelagic domain, as well as its efficiency defined as its effectiveness in reducing surface nutrients relative to subsurface values (Sarmiento et al., 2004). The efficiency of vertical export can be assessed through the vertical attenuation of POC below the euphotic zone, as discussed in detail by Buesseler and Boyd (2009). It is clear that regional differences exist in the strength, overall export efficiency and depth-dependent export efficiency of the biological pump, and these differences are driven by the structures of pelagic communities, which ultimately determine the magnitude of the biological sequestration of carbon in the deep ocean and sediments.

Table 1: General characteristics of the experiments considered in this synthesis (grey shading indicates artificial iron fertilization experiments).

\begin{tabular}{|c|c|c|c|c|c|}
\hline Acronym & Region & Latitude & Longitude & Period of the year & Year \\
\hline Antarktis X/6 ${ }^{\mathrm{a}}$ & Atlantic sector & $47^{\circ} \mathrm{S}-60^{\circ} \mathrm{S}$ & $6^{\circ} \mathrm{W}$ & $\begin{array}{l}\text { September- } \\
\text { November }\end{array}$ & 1992 \\
\hline Antarktis XIII $/ 2^{\mathrm{b}}$ & Atlantic sector & $49^{\circ} \mathrm{S}-52^{\circ} \mathrm{S}$ & $6^{\circ} \mathrm{E}-12^{\circ} \mathrm{E}$ & December-January & $\begin{array}{c}1995- \\
1996\end{array}$ \\
\hline SOIREE $^{\mathrm{c}}$ & Australian sector & $61^{\circ} \mathrm{S}$ & $140^{\circ} \mathrm{E}$ & February & 1999 \\
\hline CARUSO/EisenEx ${ }^{\mathrm{d}}$ & Atlantic sector & $48^{\circ} \mathrm{S}$ & $21^{\circ} \mathrm{E}$ & November & 2000 \\
\hline $\mathrm{SOFeX}^{\mathrm{e}}$ & Pacific sector & $\begin{array}{l}56^{\circ} \mathrm{S} \\
67^{\circ} \mathrm{S}\end{array}$ & $\begin{array}{l}172^{\circ} \mathrm{W} \\
172^{\circ} \mathrm{W}\end{array}$ & January-February & 2002 \\
\hline $\mathrm{EIFeX}^{\mathrm{f}}$ & Atlantic sector & $49^{\circ} \mathrm{S}-51^{\circ} \mathrm{S}$ & $1^{\circ} \mathrm{E}-4^{\circ} \mathrm{E}$ & February-March & 2004 \\
\hline $\mathrm{SAGE}^{\mathrm{g}}$ & Pacific sector & $47^{\circ} \mathrm{S}$ & $172^{\circ} \mathrm{E}$ & March-April & 2004 \\
\hline KEOPS $1^{\mathrm{h}}$ & Indian sector & $49^{\circ} \mathrm{S}-53^{\circ} \mathrm{S}$ & $71^{\circ} \mathrm{E}-78^{\circ} \mathrm{E}$ & January-February & 2005 \\
\hline CROZEX $^{\mathrm{i}}$ & Indian sector & $43^{\circ} \mathrm{S}-49^{\circ} \mathrm{S}$ & $47^{\circ} \mathrm{E}-56^{\circ} \mathrm{E}$ & November-January & $\begin{array}{r}2004- \\
2005\end{array}$ \\
\hline LOHAFEX & Atlantic sector & $47^{\circ} \mathrm{S}-49^{\circ} \mathrm{S}$ & $14^{\circ} \mathrm{W}-16^{\circ} \mathrm{W}$ & January-March & 2009 \\
\hline
\end{tabular}

a, Smetacek et al. (1997); b, Strass et al. (2002a); c, Boyd et al. (2000); d, Smetacek (2001); e, Coale et al. (2004); f, Smetacek (2005); g, Harvey et al. (2011); h, Blain et al. (2007); i, Pollard et al. (2009); j, Smetacek (2010)

The Southern Ocean holds a special place in view of its possible impact on the 
biogeochemistry of the world ocean. The Southern Ocean contains the largest HNLC area of the world ocean. The Polar Frontal Region (PFZ) is the site of Antarctic Intermediate Water (AAIW) formation. In the PFZ nutrient (nitrate, phosphate, silicic acid) signatures are known to be influenced by iron-regulated diatom blooms (de Baar et al., 1995). The circulation of AAIW redistributes major nutrients to lower latitudes and controls the dynamics of primary producers over large regions of the world ocean, directly influencing the biological pump at the global scale. Changes in biogeochemical cycles of nitrogen and silicon, as a result of increased inputs of dissolved iron in the Southern Ocean, have been suggested to explain the difference in values of atmospheric $\mathrm{pCO}_{2}$ between the last glacial maximum and the period just preceding the Anthropocene (Brzezinski et al., 2002; Matsumoto et al., 2002).

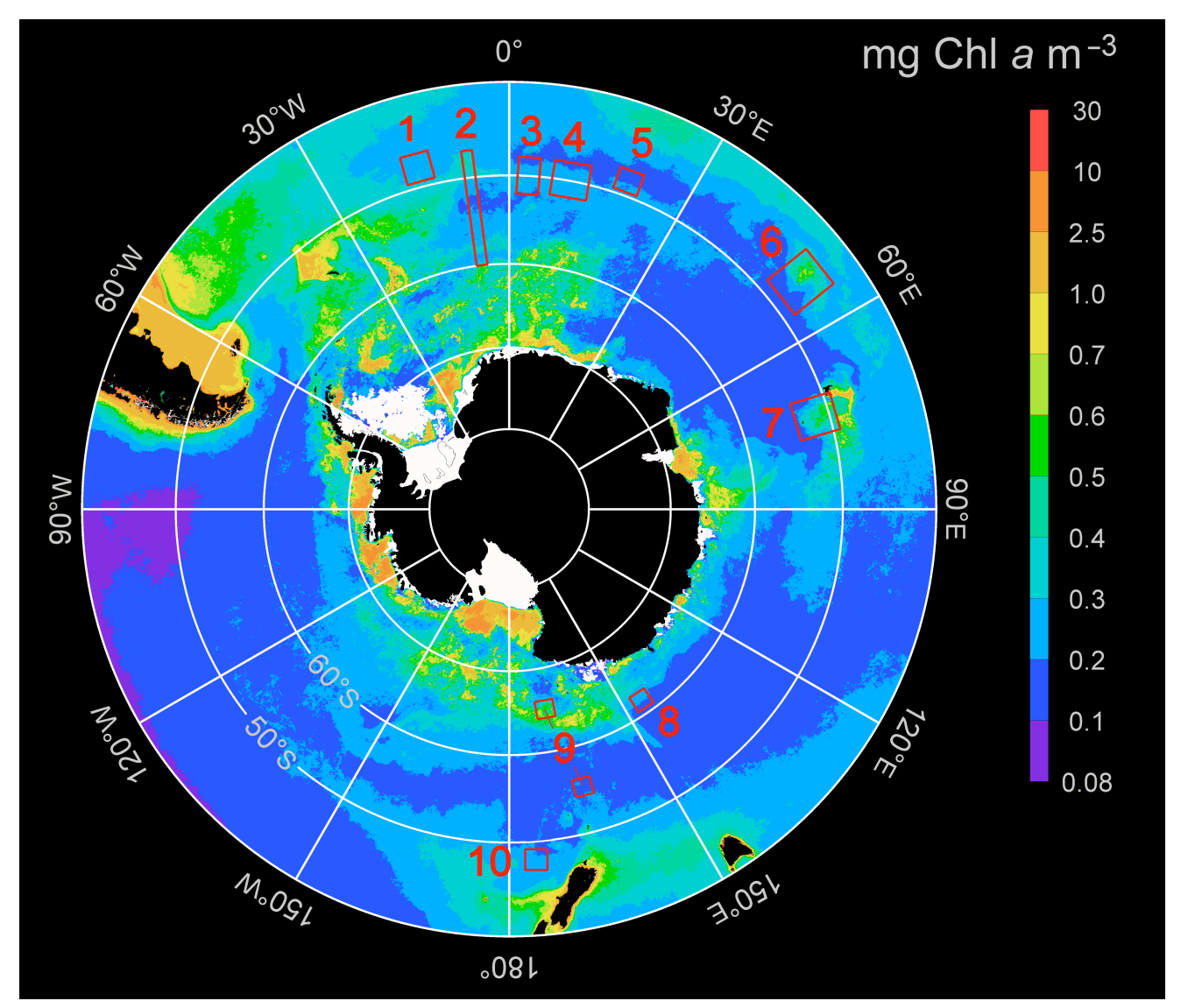

Figure 1: July 2002 to March 2012 MODIS composite of chlorophyll in the Southern Ocean. Approximate locations of the natural and artificial fertilization experiments discussed in this paper are superimposed (red rectangles): 1, LOHAFEX; 2, Antarktis X/6; 3, EIFeX; 4, Antarktis XIII/2; 5, CARUSO/EisenEx; 6, CROZEX; 7, KEOPS 1; 8 SOIREE; 9, SOFeX (North and South patches); 10, SAGE. Although satellite data are lower by a factor of approximately 2 in the bloom areas (Venables et al., 2007) the composite image clearly shows elevated chlorophyll a concentrations within regions of shallow or complex topography. 
In this review paper, results are analyzed from several experiments that were conducted in recent years (see Table 1 and Figure 1) in the Atlantic, Indian, and Pacific sectors. The goal of this paper is to extract key information about the role of iron in structuring pelagic communities at the first trophic levels. This review is restricted to ice-free regions of the Southern Ocean, which are characteristic of the Permanently Open Ocean Zone (POOZ) and the Polar Frontal Zone (PFZ), regions where no large krill swarms have been reported. The objective of the exercise is to summarize the observations which were made in several major studies of natural or artificial iron fertilizations in order to 1) gain insights into the causes of productive ecosystems in the Southern Ocean, 2) build a conceptual framework, and 3) identify avenues of research priority to be tested in the future by a next generation of either natural or artificial iron fertilization experiments.

\section{Plankton community structures in the Southern Ocean}

\subsection{The HNLC area}

POOZ of the Southern Ocean is the largest HNLC area of the world ocean. Phytoplankton blooms are rare in the POOZ and most of the time (i.e. in the absence of significant iron inputs to surface waters) the POOZ pelagic ecosystem shows low primary production, with small phytoplankton fueling a weak biological pump that is characterized by high protistan grazing, and efficient remineralization of fixed carbon and nutrients (Landry et al., 2002). Consequently, the mesozooplankton, even when present, play a weak role in phytoplankton grazing although salps or appendicularians can sometimes have a much more significant impact than copepods (Mayzaud et al., 2002). At times, occasional salp swarms, often represented by Salpa thompsoni, can be efficient grazers able to remove an amount of organic carbon almost equivalent to all of the primary production (Pakhomov et al., 2002; Atkinson et al., 2004). The dominant copepods are commonly small species such as Oithona similis (Takahashi et al., 2010), and these contribute to the conservation of mass and the recycling efficiency of biogenic elements in the surface layer (Pond and Ward, 2011).

\subsection{Areas naturally fertilized by iron}

Within the HNLC environment of the Southern Ocean a few oases of greenery can be distinguished (Figure 1). Phytoplankton blooms are frequently observed in areas where fronts interact with large bathymetric features, such as ridges, islands, and plateaux. The first in situ monitoring of a bloom associated with the natural fertilization by iron was conducted, more or less accidentally, during the experiment Antarktis-X/6 'Frühling am Eisrand' in 1992. Under the combined effects of mixed-layer shallowing due to mesoscale structures driven by the interaction between Antarctic Circumpolar Current (ACC) and the bathymetry, and the increase of day length in the spring, a diatom bloom developed in the Antarctic Polar Front (APF) under the iron-replete 
initial condition. The blooms at the PFZ were dominated by the large heavily silicified Fragilariopsis kerguelensis, Corethron inerme and Corethron pennatum, while the smaller Pseudonitzschia prolongatoides and Cylindrotheca closterium were restricted to the south of the PFZ where no bloom developed at the same time (Bathmann et al., 1997). Although the vertical fluxes were not measured, the maximum penetration depth of the biogenic silica suggested an export of biomass out of the surface layer towards deep waters (Quéguiner et al., 1997, Smetacek et al., 1997). This was supported by the evolution of the ${ }^{234} \mathrm{Th} /{ }^{238} \mathrm{U}$ ratio (Rutgers van der Loeff et al., 1997, 2002). Within the bloom, the zooplankton community was dominated by the cyclopoid copepods Oithona similis and Oncaea sp. (Fransz and Gonzalez, 1997), and their grazing on large diatoms was therefore unlikely, as mentioned by Rutgers van der Loeff et al. (2002). The observation of many empty frustules and the possible role played by microzooplankton (Klaas, 1997) suggest that the vertical export of such a bloom is related to massive diatom sinking instead of stemming from mesozooplankton grazing. It is also worth mentioning the presence, close to the bloom area, of Salpa thompsoni that have a significant capacity to feed on microzooplankton and may be an important link from microbial food webs to macrozooplankton and vertical export (Gowing, 1989; Dubischar et al., 1997).

The seasonal evolution of pelagic ecosystems in the Atlantic sector was studied four years later during the experiment Antarktis-XIII/2 "Frontendynamik und Biologie," which extended the observations to the early summer, probably under iron-enrichment conditions that differed from the previous cruise (Strass et al., 2002b). The PFZ was still productive at this time of the year, diatoms were still the main phytoplankton components in terms of biomass, and the system appeared to operate at steady-state. The production was fairly evenly distributed among the pico-, nano- and microphytoplankton, indicating that the accumulation of diatom biomass is not only the simple result of increased growth but also reflects their resistance to grazing (Tremblay et al., 2002). Fragilariopsis kerguelensis and Corethron pennatum occurred in low numbers, and the dominant diatoms were represented by different species (Pseudo-nitzschia cf. lineola, Chaetoceros atlanticus, and Thalassiothrix antarctica) than in spring (Smetacek et al., 2002). This reflects the existence of a seasonal succession related to the gradual establishment of a limitation by silicic acid (Quéguiner et al., 1997; Tremblay et al., 2002). Healthy Thalassiothrix antarctica was the dominant species responsible for the accumulation of biogenic silica. This accumulation was sometimes restricted to the lower part of the mixed layer, in areas where silicic acid was depleted in surface waters. This observation shows that, under conditions of growth limitation, even by silicic acid, some heavily silicified large-sized diatoms, so-called "giant diatoms," can dominate the phytoplankton biomass (Kemp et al., 2000). The low growth rates of these giant diatoms in the form either long-chain (e.g. Fragilariopsis kerguelensis) or large individuals cells (e.g. Thalassiothrix antarctica) promote an 
increased silicification of their frustules. The longer duration of their cell cycles produces a longer duration of opal deposition (Claquin et al., 2002). In turn, this strong silicification allows them to be particularly resistant to grazing by mesozooplankton (Hamm et al., 2003). The accumulation of these diatoms occurs over a time scale on the order of several months, much longer than the duration of any artificial iron fertilization experiment accomplished in the past. The summer zooplankton populations in the PFZ had extremely high biomass, of the same order of magnitude as that of phytoplankton. The dominant copepods were again the small Oithona similis, Oithona frigida, and Ctenocalanus citer which fed on delicate Ps. cf. lineola but apparently not on large colonies of $C$. atlanticus, nor on giant cells of Thalassiothrix antarctica (Dubischar et al., 2002; Pollard et al., 2002; Smetacek et al., 2002). Oithona feeding must however be considered with caution: its gut contents may not necessarily reflect its real food regime, because this copepod can eat fecal pellets of other species which could include nanoplankton and protozoans (Atkinson, 1998).

The two experiments, KErguelen Ocean and Plateau compared Study (KEOPS 1) (Blain et al., 2007) and Crozet Natural Iron Bloom and Export Experiment (CROZEX) (Pollard et al., 2009) provided further information about the pelagic ecosystem structure in naturally iron-fertilized areas of the ACC downstream of Kerguelen and Crozet Islands, respectively. These experiments covered a critical portion of a seasonal cycle: KEOPS 1 characterized the end of the productive period while CROZEX characterized the late spring and early summer.

The results obtained during CROZEX confirmed that the early stages of the bloom under natural iron fertilization are dominated by large diatoms: Corethron pennatum and Eucampia antarctica. They were probably the first to develop, and their growth lasted till the limitation of silicic acid availability. Smaller Thalassionema nitzschioides and the prymnesiophyte Phaeocystis antarctica tended to dominate the coastal assemblage (Poulton et al., 2007). Outside the fertilized area of typical HNLC waters, Fragilariopsis kerguelensis and $C$. pennatum were of dominant species, together with the large colony-forming Dactyliosolen antarcticus and T. nitzschioides, Pseudo-nitzschia spp. and Chaetoceros spp. (Poulton et al., 2007; Salter et al., 2007). The mesozooplankton community was overwhelmingly composed of copepods, which did not display any major temporal evolution over the 3-month study period from early November to late January. Fieldings et al. (2007) have distinguished a neritic assemblage dominated by the medium-sized Drepanopus pectinatus and an oceanic assemblage dominated by the large Rhincalanus gigas, while Oithona similis was present in both communities. One major finding is that grazing by copepods had little effect on the phytoplankton standing stock, regardless of the area, but it played an important role in consuming more than $90 \%$ of the primary production in the HNLC area, especially at the end of the productive period when primary production was essentially dominated by picophytoplankton (Fieldings et al., 2007; Seeyave et al., 2007). With regards to the vertical export of biogenic 
materials, E. antarctica seemed to act as a particularly important player (Salter et al., 2007). The vertical flux collected by sediment traps was dominated by Fr. kerguelensis in the HNLC area and by E. antarctica in the iron-enriched bloom areas, although the latter species only accounted for a small fraction of the phytoplankton observed in the surface mixed layer (Salter et al., 2007).

During KEOPS 1, at the end of the plateau bloom, successive water samples at the bloom reference station revealed an evolution of the plankton community from an assemblage dominated by delicate Chaetoceros, subgenus Hyalochaete, to a remnant assemblage dominated by Eucampia antarctica (Quéguiner et al., 2011). The initial assemblage was dominated by Chaetoceros debilis, Fragilariopsis kerguelensis, Navicula sp., Thalassionema nitzschioides, E. antarctica, and Membraneis sp. In the final assemblage E. antarctica was often present as resting stages and accompanied by Fr. kerguelensis, Corethron inerme, Leptocylindrus danicus, and Guinardia cylindrus (Armand et al., 2008a). This diatom assemblage was similar to that observed previously in early spring within a phytoplankton plume northeast of Kerguelen where Fr. kerguelensis was dominant together with Pseudo-nitzschia spp. and Thalassiosira spp. (Blain et al., 2001). In contrast with the situation on the plateau and the importance of large centric diatoms, the phytoplankton assemblages observed during the successive visits to the HNLC reference station always showed the dominance by heavily silicified diatoms, Fr. kerguelensis, the large Thalassiosira lentiginosa and Thalassiosira antarctica, and the very small Fragilariopsis pseudonana with varying, elevated proportions of dead cells (Armand et al., 2008a). During KEOPS 1, at the center of the bloom of the naturally fertilized area, the comparison between water samples and net tows revealed the presence of two different diatom communities. By contrast to the assemblages described above, net tows were dominated by large colonies of the heavily silicified pennate diatoms Fr. kerguelensis accompanied by the giant Thalassiothrix antarctica (Armand et al., 2008a). There is limited information about the nature of vertical export during KEOPS 1. Examinations of some surficial sediment thanatocoenoses indicated a predominance of the heavily silicified diatoms, which are probably the major players in the vertical flux (Armand et al., 2008b). Over the plateau, the siliceous sediments were dominated by remnants of Fr. kerguelensis, T. nitzschioides, and Chaetoceros Hyalochaete resting spores, and to a lesser extent by frustules of Thalassiosira antarctica and E. antarctica. The HNLC sediments reflected the surface water assemblages and were dominated by Fr. kerguelensis, T. lentiginosa and Thalassiothrix antarctica. The zooplankton community was dominated by copepods. In the HNLC area, calanoid copepods of large size (Calanus simillimus, Calanus propinquus, Metridia lucens, Paraeuchaeta sp., Pleuromamma robusta and Rhincalanus gigas) and medium size (late copepodite and adult stages of Clausocalanus spp. and Microcalanus spp.) as well as small size (Oithona similis, Oithona frigida and Oncaea sp.) composed the bulk of the biomass (Carlotti et al., 2008). Over the Kerguelen Plateau the composition of the copepod assemblage was still the same but with a 
higher biomass, a high proportion of nauplii and a significant fraction of mesozooplankton sporadically associated with pteropods. Direct grazing on phytoplankton by mesozooplankton seemed low (Carlotti et al., 2008). It is possible that the mesozooplankton fed on microzooplankton, since microzooplankton biomass was found to be particularly low in both the iron-enriched area and the HNLC area (Christaki et al., 2008).

\subsection{Artificial iron fertilization experiments}

During the Southern Ocean Iron Enrichment Experiment (SOIREE), two haptophyte groups, with pigment signatures respectively typical of Phaeocystis sp. and coccolithophores increased steadily during the first 8-10 days, and then decreased somewhat. On day 13, the in-patch community was dominated by diatoms notably the chain-forming pennate Fragilariopsis kerguelensis, and also Rhizosolenia sp. and Pseudo-nitzschia sp. (Gall et al., 2001). Various very large diatom species were present, albeit with low numbers. However, they exerted a large impact on total biomass given their size. These included in particular Thalassiothrix antarctica, Asteromphalus flabellatus, Trichotoxon reinboldii, Nitzschia cf. sicula, Coscinodiscus spp., Eucampia antarctica, and various Navicula spp. (Waite and Nodder, 2001). The zooplankton community was composed of the late larval stages of the large copepods, Calanoides acutus and Rhincalanus gigas, which accounted for the bulk (87\%) of the biomass, small copepodites of Ctenocalanus spp. and Calanoides acutus, as well as copepodites and adults of the small Oithona similis, which were the most numerically abundant (Zeldis, 2001).

During the initial phase of the EisenEx/CARbon dioxide Uptake by the Southern Ocean (CARUSO) Experiment, the microplanktonic diatoms were dominated by Fragilariopsis kerguelensis with a mean depth-integrated abundance of 5,737 cells $\mathrm{L}^{-1}$ at day 0 of the experiment. This species increased up to 22,146 cells $\mathrm{L}^{-1}$ inside and 9,389 cells $\mathrm{L}^{-1}$ outside the patch by day 21 . Chain lengths on the order of 4-30 cells per chain were indicative of favorable growth, with maximum observed lengths up to 160 cells/chain (de Baar et al., 2005). The dominant diatom species at the initial phase of the experiment were: Dactyliosolen antarcticus, Fr. kerguelensis, Haslea trompii, Corethron pennatum, and Guinardia delicatula, as well as unidentified discoid diatoms (Assmy et al., 2007). Two delicate diatom species, the centric Chaetoceros debilis and the pennate Pseudo-nitzschia lineola, increased their population concentrations exponentially throughout the experiment to 150-times and 90-times initial values, respectively. Because $C$. debilis initial abundance was one tenth that of $P$. lineola, the two contributed $1 \%$ and $21 \%$ to bloom biomass at the end of the experiment, respectively, highlighting the role of seeding in a bloom formation (Assmy et al., 2007). There was some evolution of the $>50 \mu \mathrm{m}$ protozooplankton assemblages although no clear differences could be observed between assemblages inside and outside the patch, and the 
biomass did not show any major evolution in both environments (Henjes et al., 2007a). Grazing pressure by copepods, especially nauplii of Ctenocalanus spp. and Oithona spp., and copepodite stages of Oithona similis, was responsible for the decline of aplastidic dinoflagellates and ciliates, resulting in a decreased grazing pressure over diatoms. Henjes et al. (2007b) concluded that this trophic cascade favored dominance of the bloom by large diatoms.

Only limited information on the structure of plankton communities is available for the Southern Ocean Iron Experiment (SOFeX). Under high nitrate, low silicic acid, conditions of the northern fertilized patch, Coale et al. (2004) and Peloquin and Smith (2007) reported an increase of larger $(>5 \mu \mathrm{m})$ cells within a mixed phytoplankton community composed of prymnesiophytes (incl. Phaeocystis sp.), pelagophytes, dinoflagellates, and the delicate diatom Pseudo-nitzschia sp. In the southern fertilized patch, otherwise characterized by high nitrate and high silicic acid concentrations, the phytoplankton community was dominated by diatoms, and the iron addition apparently did not modify the structure of the community (Coale et al., 2004) which primarily consisted of Corethron spp., Chaetoceros spp., Rhizosolenia spp., Fragilariopsis spp. and Asteromphalus spp. (Peloquin and Smith, 2007).

During the European Iron Fertilization Experiment (EIFeX), the biomass distribution of the total diatom community showed a relative decrease in large Chaetoceros species, while Thalassiothrix antarctica, Corethron inerme, and large rhizosolenoids (including Guinardia, Proboscia, and Rhizosolenia species) increased. Other species, like Fragilariopsis kerguelensis, Pseudo-nitzschia spp., and Dactyliosolen antarcticus, were important in terms of biomass throughout the whole experiment, with only minor changes in their relative contribution to the total diatom biomass (Hoffmann et al., 2006). Inside the iron-enriched patch the mesozooplankton were dominated by the large-sized Rhincalanus gigas and Calanus simillimus and the medium-sized Ctenocalanus citer, while outside the patch the mesozooplankton were predominantly medium sized. Grazing had a moderate impact on the phytoplankton standing stock, with grazing occurring at a rate up to $\sim 1 / 3$ of the primary production in the bloom (Krägefsky, 2008).

The SOLAS Air-sea Gas Exchange (SAGE) experiment has proven unique because fertilization resulted in only a small increase in biomass (doubled) resulting from the growth of nonsiliceous phytoplankton (Peloquin et al., 2011). Fertilization enabled a unique development of picoeukaryotes, which was interpreted as reflecting a persistent limitation of diatoms by iron and silicic acid, associated with significantly lower iron needs of the picoplankton community. Under these conditions, the microzooplankton biomass doubled as a result of active predation on picoeukaryotes and possibly the absence of grazing by copepods. 
During the Indo-German iron fertilization experiment (LOHAFEX), the initial phytoplankton assemblage was dominated by small flagellates including prymnesiophytes, e.g. Emiliania huxleyi, solitary cells of Phaeocystis antarctica and other unidentified species, and unidentified prasinophytes, cryptophytes, choanoflagellates and coccoid cells (Assmy et al., 2010). After iron fertilization, a slight increase in cell numbers was observed for some diatoms such as Fragilariopsis kerguelensis, Corethron pennatum, Thalassionema nitzschioides, and species of the genera Thalassiosira and Pseudo-nitzschia. However, this development stopped very quickly, and biomass concentrations measured inside and outside of the fertilized patch did not differ significantly (Assmy et al., 2010). The study also showed that protozooplankton were co-dominated by heterotrophic dinoflagellates of Protoperidium and naked species, and tintinnids. The presence of many empty and crushed tintinnid loricae in water samples and copepod fecal matter is interpreted as an indication of the high grazing pressure on protozooplankton, such that the flagellate biomass was rapidly transformed into the larger mesozooplankton community (Assmy et al., 2010). The mesozooplankton community was dominated by late copepodite stages of Calanus simillimus outside the patch, and adults and juveniles of Oithona similis and Ctenocalanus citer inside the patch (Mazzocchi et al., 2010). Finally, LOHAFEX stands out relative to other fertilization experiments because of the presence in the study area of abundant amphipod Themisto gaudichaudii, an efficient predator of copepods, especially inside the fertilized patch (Mazzocchi et al., 2010).

\section{Iron and other environmental factors shaping the plankton community structure in}

\section{the Southern Ocean}

Synthesizing a complete dataset for seasonal community structures is difficult, given that the data were acquired during many experiments conducted at different times of different years in different geographic locations, in different nutritional environments, and under varied physical conditions. However by comparing the results of artificial fertilization experiments and studies of natural fertilization, it may be possible to identify major features of the dynamics of pelagic communities in the Southern Ocean POOZ and the PFZ. This is the goal of this section.

The main difference between artificial and natural iron fertilization experiments is that in artificial iron experiments, the early development of all primary producers can be witnessed while in the natural iron fertilization observations depend on the stage of community development, not only of the phytoplankton but also of the entire pelagic food web at the beginning of the study. An iron fertilization experiment, whether natural or artificial, will at first result in the development of phytoplankton blooms. Following the classical paradigm illustrated by Margalef's (1978) mandala, these phytoplankton populations are often dominated by large size classes: microphytoplankton accumulate biomass most rapidly, and their potential vertical export of carbon is directly determined 
by forming aggregates or indirectly through fecal pellets of grazers as the so-called classical food web (Buessler, 1998; Calbet and Landry, 2004). Although in every bloom, all size classes (pico-, nano-, and microphytoplankton) grow rapidly during the initial stage, biomass rapidly accumulates almost exclusively in diatoms (Gall et al., 2001; Gervais et al., 2002; Tsuda et al., 2003; Marchetti et al., 2006; de Baar et al., 2005; Boyd et al., 2007; Smetacek and Naqvi, 2008).

\subsection{Iron, silicic acid, and light}

Some experimental results, however, contradict the above scenario and illustrate the role also played by major nutrients. Several studies focused on the role of silicon in limiting the diatom growth, even in the HNLC waters of the Southern Ocean (Boyd et al., 1999; Quéguiner, 2001; Nelson et al., 2001; Mosseri et al., 2008). Degrees of silicon limitation and iron availability are correlated pointing out the possibility of co-limitation (Quéguiner, 2001). In high nutrient, low silicic acid, low chlorophyll (HNLSiLC) waters, the SAGE experiment indicates that a major nutrient limitation is still likely to occur during the development of phytoplankton blooms after iron fertilization, and can lead to drastic changes in group dominance. Peloquin et al. (2011) showed that silicic acid limitation can stop diatom growth, thus shifting the dominance to other groups including picoeukaryotes. The low silicic acid of the LOHAFEX experiment also prevented diatom blooms, and instead the artificial iron fertilization stimulated development of a diversified assemblage of small nanoflagellates, which were the main contributors to the total phytoplankton biomass (Assmy et al., 2010). Mosseri et al. (2008) indicated that diatoms of the KEOPS 1 study area were limited by silicic acid availability even within the bloom, which was at its final stage. Armand et al. (2008a) attributed the shift in diatom dominance at the end of the Kerguelen Plateau bloom to a progressive increase of silicon limitation. During CROZEX, a sharp decrease of silicic acid during the course of the bloom likely drove the species succession that ultimatelyy resulted in Phaeocystis antarctica dominance (Poulton et al., 2007). In the same vein, the dominance within the group of diatoms can also be affected by the concentration of added metal relative to the natural concentration of silicic acid. This is how Leblanc et al. (2005) explain the competition between large cells of the colonyforming Pseudo-nitzschia sp. and the small, less silicified solitary pennate Cylindrotheca closterium.

Shortly after the first experimental evidence of phytoplankton growth limitation by iron in the Southern Ocean (de Baar et al., 1990; Martin et al., 1990), the importance of vertical mixing in limiting the light field of a phytoplankton cell was also examined (Mitchell and Holm-Hansen, 1991). An inverse relationship between phytoplankton standing crop and the depth of the surface mixed layer was revealed. Mitchell et al. (1991) estimated that, for a minimum loss rate $\left(\sim 0.2 \mathrm{~d}^{-1}\right)$ and typical conditions of stratification and irradiance in the ACC, phytoplankton are unable to utilize more than $10 \%$ of the available macronutrients before they become light-limited by self-shading. 
Nelson and Smith (1991) indicated that the highest chlorophyll $a$ levels that can be sustained in summer in open waters not stabilized by melt water are $\sim 1.0 \mu \mathrm{g} \mathrm{L}^{-1}$ in the Weddell and Scotia Seas and probably less in areas experiencing stronger winds. Light limitation is not independent of iron limitation, as iron requirements are increased for photoacclimation under low light conditions (Venables and Moore, 2010). Several studies have documented the increase of photosynthetic competence of photosystem II ( $\mathrm{F}_{\mathrm{v}} / \mathrm{F}_{\mathrm{m}}$ ratio) in response to iron availability (Boyd et al., 1999; Olson et al., 2000; Boyd and Abraham, 2001; Sosik and Olson, 2002; Hiscock et al., 2003; Moore et al., 2007). During SOIREE, iron fertilization resulted in a two-fold increase of $F_{v} / F_{m}$ within the fertilized patch (Boyd and Abraham, 2001). Hiscock et al. (2008) reported an immediate and sustained increase in the maximum quantum yield $\left(\phi_{\mathrm{m}}\right)$ of total phytoplankton, an indicator of the photosynthetic efficiency, in response to iron addition during SOFeX. Moore et al. (2007) also concluded that interactions between iron and light availability influenced phytoplankton photophysiology and growth through the interplay between photochemical efficiency and photoinhibition, and potentially contributed to bloom longevity in the CROZEX area. The southward progression of the bloom was also controlled by light availability, but the spatial variability of the bloom was probably controlled by the iron supply. The bloom ends before light becomes a limiting factor (Venables et al., 2007).

Iron and light play critical roles in mediating carbon export from the Southern Ocean mixed layer (Cassar et al., 2011). Studies of the role of light have indicated that when deep mixed layers occur in the Southern Ocean, phytoplankton adapt poorly to low light due to the iron deficiency of surface waters. Under these conditions the early accumulation of biogenic matter in surface waters quickly leads to the self-shading of phytoplankton. In these circumstances, iron deficiency is probably responsible for the fact that surface diatoms have low affinity for silicic acid. In areas that are naturally iron fertilized, at the end of the productive season, lowered concentrations of silicic acid and iron deficiency severely limit the growth of diatoms in surface waters. Diatoms that accumulate at the base of the mixed layer transiently find a niche in the vertical gradient of iron and silicic acid where iron limitation is somewhat relieved, enabling some photoadaptation as well as an increase in the affinity to silicic acid. This situation lasts as long as daily light is sufficient to ensure minimum photosynthetic activity. Fall intensification of vertical mixing, combined with reduced incident irradiance, is prone to disperse these accumulations and to release a pulse of sediment into deeper water.

\subsection{Does grazing matter?}

The accumulation of biomass of phytoplankton is the result of the balance between growth and mortality. In the case of iron fertilization, biomass can accumulate because of increased 
phytoplankton growth rates. If the biomass within some size classes is strongly limited despite a high growth rate, this implies a correspondingly elevated mortality rate. The trophic interaction through grazing and mortality makes the evolution of plankton community structure more complex than it would appear at first glance.

Because protozooplankton can grow and divide as rapidly as phytoplankton cells, they can control pico- and nanophytoplankton (Calbet and Landry, 2004; Peloquin et al., 2011). Protozooplankton do not restrict their foraging activities to the small size classes of phytoplankton, and they can efficiently consume diatoms among microphytoplankton, ingesting prey several times larger than their body length (Calbet, 2008). For example, the increase in grazing pressure on Chaetoceros debilis by Gyrodinium sp. and Gyrodinium spirale was reported by Saito (2006) during SEEDS. For this reason several authors invoke selective grazing of faster-growing protozoa by copepods (Kleppel et al., 1991; Christaki et al., 2008; Saiz and Calbet, 2011) as a mechanism to relieve grazing pressure on large diatoms, enabling them to bloom (Assmy et al., 2007). This reduction in grazing pressure from protozooplankton should also promote the increase in biomass of small size classes of phytoplankton, though it has not been observed in situ. We can hypothesize that a cascading effect arises fairly quickly (on time scales of weeks) after the start of the bloom, which drives a pelagic ecosystem with top-down controls of pico- and nanophytoplankton by protozooplankton and then by mesozooplankton. Carlotti et al. (2008) indicated that, during KEOPS 1, stocks of ciliates and heterotrophic nanoflagellates were probably controlled by mesozooplankton, especially during the later stage of a bloom, when they provided sufficient food to cope with the decrease in phytoplankton stocks. Nevertheless, microzooplankton grazing represents the major loss term for primary production across a broad range of marine regions and habitats from estuaries to open oceans and from tropical to polar areas (Calbet and Landry, 2004). Sherr and Sherr (2007) stress that some components of protozooplankton, e.g. heterotrophic dinoflagellates, are likely to be an important food resource for mesozooplankton, thereby linking the microbial network to the classical food web. Adding more complexity, in some occasions such as SEEDS II, copepod grazing controlled the food web structure at the lower trophic levels, keeping the diatom biomass at a very low level (Tsuda et al., 2009). As summarized by Calbet (2008), more information is needed to better understand the roles played by protozooplankton in ecosystem dynamics.

Smetacek and Naqvi (2008) challenged the importance of grazing in artificial iron fertilization experiments. They indicated that all Southern Ocean iron fertilization experiments induced blooms in a range of mixed layer depths in seasons from spring to late summer. This fact indicates that "iron availability and not light or grazing controlled the build-up of biomass." Nevertheless it remains unknown which processes at the scale of phytoplankton cells are directly impacted by the suppression of iron limitation. In the vast majority of artificial iron fertilization 
experiments described above, the low grazing pressure of zooplankton on diatom standing stock is a leitmotiv. Diatoms, even weakly silicified, tend to accumulate in the surface mixed layer partly because protozooplankton are under top-down control by mesozooplankton, as described above. Other causes should nevertheless exist, because the blooms induced by artificial fertilization represent an early stage of new development stimulated by iron addition during which the mesozooplankton plays only a minor role (Zeldis, 2001; Schultes et al., 2006). We can hypothesize that different control factors are set up, probably successively, in the course of the productive period to achieve a gradual sequestration of organic matter in the surface layer. Observations made during KEOPS 1 and CROZEX suggest that, along with a low grazing pressure on diatoms, nutrients are recycled or injected to allow the maintenance of phytoplankton populations. The results of Mosseri et al. (2008) show that the diatoms in the bloom of the Kerguelen Plateau largely use ammonium, which accounts for 39 to $77 \%$ of nitrogen requirements. The Crozet bloom is also supported largely by ammonium and, even at its maximum development, the nitrate accounts for less than $67 \%$ of requirements (Lucas et al., 2007). Also nitrification in the euphotic zone appears to be an important process (Sanders et al., 2007). Bacterial activity intensifies during the productive period, probably fuelled by dissolved organic matter that is produced by nutrient-limited phytoplankton as well as by other particulate organic matter stored in the upper ocean during the post bloom phase over several months in turn replenishing regenerated nutrients in the surface layer (Obernosterer et al., 2008; Sanders et al., 2007). The difference between faster regeneration of nitrogen (and probably phosphorus) and slower regeneration of silicon gradually leads to the emergence of silicic acid limitation at the very end of the productive season.

In blooms produced by either natural or artificial fertilization, mesozooplanktonic communities are frequently dominated by copepods belonging mainly to the orders of Calanoida (Calanus propinquus, Rhincalanus gigas, Metridia lucens, Calanus simillimus, Calanoides acutus, Ctenocalanus citer, Paraeuchaeta spp., and Pleuromamma robusta), Cyclopoida (Oithona similis and Oithona frigida) and Poecilostomatoida (Oncaea spp.). The presence of small copepods is reported by only a few authors, but their frequent absence in the samples is mainly due to the inefficiency of capture by coarse nets (see Svensen et al., 2011). Copepod diet is still not well understood. It varies at the seasonal and interannual scales in relation to the life cycles of organisms and to the availability of different food resources. Several studies have indicated that small organisms of the genera Oithona and Oncoea have a predominantly omnivorous/detritivorous diet (Atkinson, 1998). Adult Oithona spp. are omnivorous with a preference for moving prey such as ciliates, while their nauplii are non-selective feeders, feeding on particles $<10 \mu \mathrm{m}$. Both link the classical food web to the microbial food web (Svensen et al., 2011). Oithona similis is reported to feed on diverse prey including autotrophic and heterotrophic flagellates and ciliates, as well as on 
copepod nauplii (Nakamura and Turner, 1997). The majority of larger Calanoida also consume a predominantly omnivorous/detritivorous diet (Atkinson, 1998; Pasternak et al., 2009). Only Calanoides acutus seem to have a preference for herbivory compared to omnivory (Atkinson, 1998; Pasternak and Schnack-Schiel, 2001), while Calanus propinquus and Rhincalanus gigas are sometimes identified as carnivores (Pasternak and Schnack-Schiel, 2001).

In the post-bloom period, zooplankton communities are likely to exert significant control on the fate of organic matter. Through complex interactions between different species and larval stages, organic matter is constantly recycled within the surface layer. In addition, by coprophagy and coprorhexy, copepods turn their fecal pellets into smaller particles that are retained within the surface layer and that can then be degraded by other organisms such as bacteria and protozooplankton (Iversen and Poulsen, 2007) or even ingested sporadically by microphagous pteropods (Carlotti et al., 2008). This retention of matter is accompanied by two processes. First there is a gradual transfer of nutrients towards the mesozooplankton, a process which is the principal cause of a weak vertical export of nitrogen and phosphorus. Second the latter are decoupled from biogenic silica, which is gradually removed from the surface layer by a silicon pump that is particularly efficient at the low surface temperatures of the Southern Ocean (Dugdale et al., 1995).

One of the remaining questions is the transfer of bacterial production to higher trophic levels, i.e., giving the low impact of grazing by protozooplankton on bacteria, Christaki et al. (2008) call this the "missing link". Zeldis (2001) also discussed "the enigma of copepod nutrition" during SOIREE, referring to the apparent lack of high density detrital material which might have been the principal food source. They questioned the role of fine-scale $(5 \mathrm{~m}$ ) vertical structures (seen in density and transmissometer data) to act as accumulation layers for biogenic matter. Such discontinuity layers are difficult to sample without disturbance, and they also vary in depth spatially and temporally, in response to internal waves, currents, episodic weather events and seasonal mixing (Robinson et al., 2010). We must therefore focus on investigating the transfer of biogenic matter between the microbial and the classical food webs, hence between the 'regeneration system' or the 'export pathway' as articulated by Sarmiento et al. (2004). This will need to incorporate a new dimension of vertical heterogeneity that seems to be present even in the Southern Ocean.

\subsection{Species successions and life cycles}

The rapid temporal succession of species is another major feature of the phytoplankton ecosystem. Saito et al. (2006) pointed out that iron inputs modify the dominant diatom bloom species, which in turn determine the overall response of the entire community. The limited information about the long-term stability of phytoplankton community structure makes it difficult to scale up the findings of artificial iron fertilization experiments (Boyd et al., 2007). During EIFeX the 
collapse of initially dominant species, Chaetoceros dichaeta and Chaetoceros atlanticus, and their successors, Fragilariopsis kerguelensis and Corethron inerme, were not clearly related to grazing by large copepods, Calanus simillimus, Rhincalanus gigas and Pleuromamma robusta (Assmy et al., 2005 ; Kruse et al., 2009). No clear signs of mechanical breakage associated with crustacean grazing were observed that might have accounted for the disappearance of $C$. dichaeta and $C$. atlanticus. Both species were found intact in copepod guts, and this was considered to be indicative of resistance to grazing. In fact, Assmy et al. (2005) reported that C. dichaeta and C. atlanticus seemed senescent, with chains of many empty cells or cells with disintegrating cytoplasm, a phenomenon that could be related to cell death due to epidemic virus and bacterial infection or programmed apoptosis. These mechanisms of apoptosis and species-specific pathogenicity have also been raised by Smetacek et al. (2002), together with grazing by small copepods, to explain the senescent condition of early summer populations of the delicate Pseudo-nitzschia spp. in the Atlantic sector of the PFZ. This could also have been the case for the decaying diatom population of the HNLC site during KEOPS 1 (Armand et al., 2008a). Assmy et al. (2007) reported that empty frustules and broken frustules tended to increase in the course of the bloom development of EisenEx caused by several potential loss processes which are not easy do deconvolute. These include viral and bacterial infections, selective or non-selective grazing by protozoa to mesozooplankton, as well as natural mortality including apoptosis. During SEEDS II some heterotrophic bacteria of CytophagaFlavobacteria-Bacteroides closely related to the genus Saprospira were observed to be able to kill eukaryotic phytoplankton such as diatoms, dinoflagellates, and prymnesiophytes (Kataoka et al., 2009). This suggested that pathogenic bacteria could also shape the community resulting from iron fertilization. Assmy et al. (2007) argued that the ratio of growth to mortality rates determines the success of a given species in an iron-induced bloom, because none of the observed individual species should be resource limited, and thus sinking losses should be decreased to their lowest level. One might therefore expect a high variability of dominant species and the success of a single species would depend on an ecological environment previously acquired, and an inoculum community of virus, bacteria, flagellates, ciliates and mesozooplankton more or less resulting from initial natural plankton populations. Within single species, growth and reproduction depend on many factors including cell size, temperature, light and nutrients (e.g. Drebes, 1966). It is therefore possible that the different species succeed one another during the productive season in successive time windows that are conditioned by physical factors such as light and temperature and probably also by their specific internal clocks. If this is true, then in terms of production and possibly of biomass accumulation, the timing of a given species development is constrained from one year to another in the open ocean by availability of nutrients, including iron, in the period corresponding to its own time window. For the smaller size classes of the pico- and nano-phytoplankton, species succession 
could also play an important role, but taxonomic changes are still far from being resolved for these tiny microorganisms. Since we cannot control the initial state of the experimentally perturbed environment, this constitutes a major obstacle to generalizing results from artificial fertilization experiments, because no experiment could be repeated under strictly identical conditions.

During an artificial iron fertilization experiment in HNLC regions, the success of a given species (or taxonomic group) seems to result from a combination of controls by nutrient limitations, selective grazing on different size classes and initial seeding stocks, all of which could in turn be controlled directly by seasonality such as internal clocks triggering growth at maximal rates under some environmentally photoperiod-related conditions (Tsuda et al., 2005; Smetacek and Naqvi, 2008). This makes artificial iron fertilization experiments very different from natural iron fertilization experiments which necessarily take into account the adjustment of various components of a food web and seasonal development of pelagic production.

\section{Iron-induced or neritic blooms?}

Smetacek and Naqvi (2008) argued that naturally iron fertilized blooms are extensions of coastal blooms, which are dominated by neritic species with a different life cycle from oceanic species, and have characteristics of heavily silicified, fast-sinking, grazing-resistant, resting spores. In a recent paper, Salter et al. (2012) also indicated that the vertical export in the iron fertilized area within the wake of Crozet Islands was primarily contributed by a rapid settling of Eucampia antarctica resting spores. They attributed the enhanced carbon export in naturally fertilized systems not to iron relief of open ocean diatoms, but rather to the advection and growth of diatom species with characteristics of island systems and subsequent flux of resting spores. This hypothesis may also apply for the Kerguelen Plateau bloom, where many Chaetoceros Hyalochaete resting spores as well as the final formation of E. antarctica resting spores were observed inside the surface mixed layer, while the surface sediment of the plateau was also characterized by the dominance of Fragilariopsis kerguelensis, Thalassionema nitzschioides and Chaetoceros Hyalochaete spores and the presence of E. antarctica and Thalassiosira antarctica (Armand et al., 2008a, b).

Armand et al. (2008b) mentioned a great abundance of Chaetoceros spores on the Kerguelen plateau. They also showed that spores were not the dominant component of the surface sediments in the northeastern plateau. Indeed in the Atlantic sector of the Southern Ocean, Chaetoceros spores have a wider distribution in glacial sediments than in interglacial sediments. However, in the wakes of the Antarctic Peninsula and South Georgia F. kerguelensis is more abundant (20 to $>50 \%$ ) than Chaetoceros spores (15 to $>50 \%$ ), and it is even dominant at some locations in modern sediments. In last glacial diatom assemblages, Chaetoceros spores are a little less abundant $(<50 \%)$ while $F$. kerguelensis retains the same overall importance $(20$ to $>50 \%)$. This is a strong indication that the 
two diatom assemblages occupy different niches and probably react in very distinct manners to iron input. The presence of Fragilariopsis kerguelensis in sedimentary thanatocoenoses throughout the POOZ thus suggests an alternative explanation that differs from Smetacek and Naqvi's (2008) hypothesis that naturally fertilized blooms are simply extensions of coastal blooms. In addition, some large species such as Thalassiothrix antarctica seem to thrive almost everywhere at background levels. Given their large size (length $>1 \mathrm{~mm}$ ) they could be part of the 'shade flora' reviewed by Sournia (1982) representing species that occur preferentially or exclusively at some discrete depth below the surface (usually, around $100 \mathrm{~m}$ depth). These species form the 'knephoplankton' meaning the wanderers of twilight (Lo Bianco, 1903 in Sournia, 1982). These species may often be undersampled by conventional means, e.g. Niskin bottles, as discussed by Quéguiner et al. (2011). de Baar et al. (2005) also pointed that despite sporadic observations in fertilized patches, very large taxa such as Rhizosolenia, Thalassiothrix, Thrichotoxon, Asteromphalus, and Actinocyclus should not be overlooked because, in terms of biomass, the giant diatoms may reach higher levels than the numerically more abundant smaller diatoms. In fact, these giant diatoms, known as "the thistles of the plankton meadows" (Smetacek, 2000), are observed in practically all natural and artificial iron fertilization experiments, and in some artificial fertilization experiments, such as SOIREE, their growth was more representative of iron relief of open ocean diatoms. Even during SAGE, despite the very low concentrations of silicic acid and dominance by picoeukaryotes, the genera Thalassiothrix and Dactyliosolen were still persistent.

On the other hand, a deep biogenic silica maximums (DSM), located at the base of the mixed layer, was found several times in remote areas far from islands. These DSMs correspond to the accumulation of large diatoms (Bathmann et al., 1997; Kopczyńska et al., 2001; Quéguiner et al., 2011; de Salas et al., 2011). These large diatoms probably find a compromised environment at depth where light limitation is not severe, major nutrients and iron are brought in small but sufficient amounts by diffusion through the pycnocline where their combined slow growth rates and resistance to grazing allow a progressive biomass build-up in the course of their productive season. $F$. kerguelensis is a good example of this type of organism with a heavily silicified architecture protecting it from grazing (Hamm et al., 2003; Wilken et al., 2011). At the onset of winter conditions, the deepening of the mixed layer is the major process responsible for a massive export of these giant players, by a process similar to the "fall dump" (Kemp et al., 2000). In all cases, including a neritic bloom exported to deep oceanic areas or bloom development under typical HNLC conditions, inefficiency of grazing by copepods appears to be the key to the selective export of silica in the POOZ as well as in the PFZ of the Southern Ocean. 


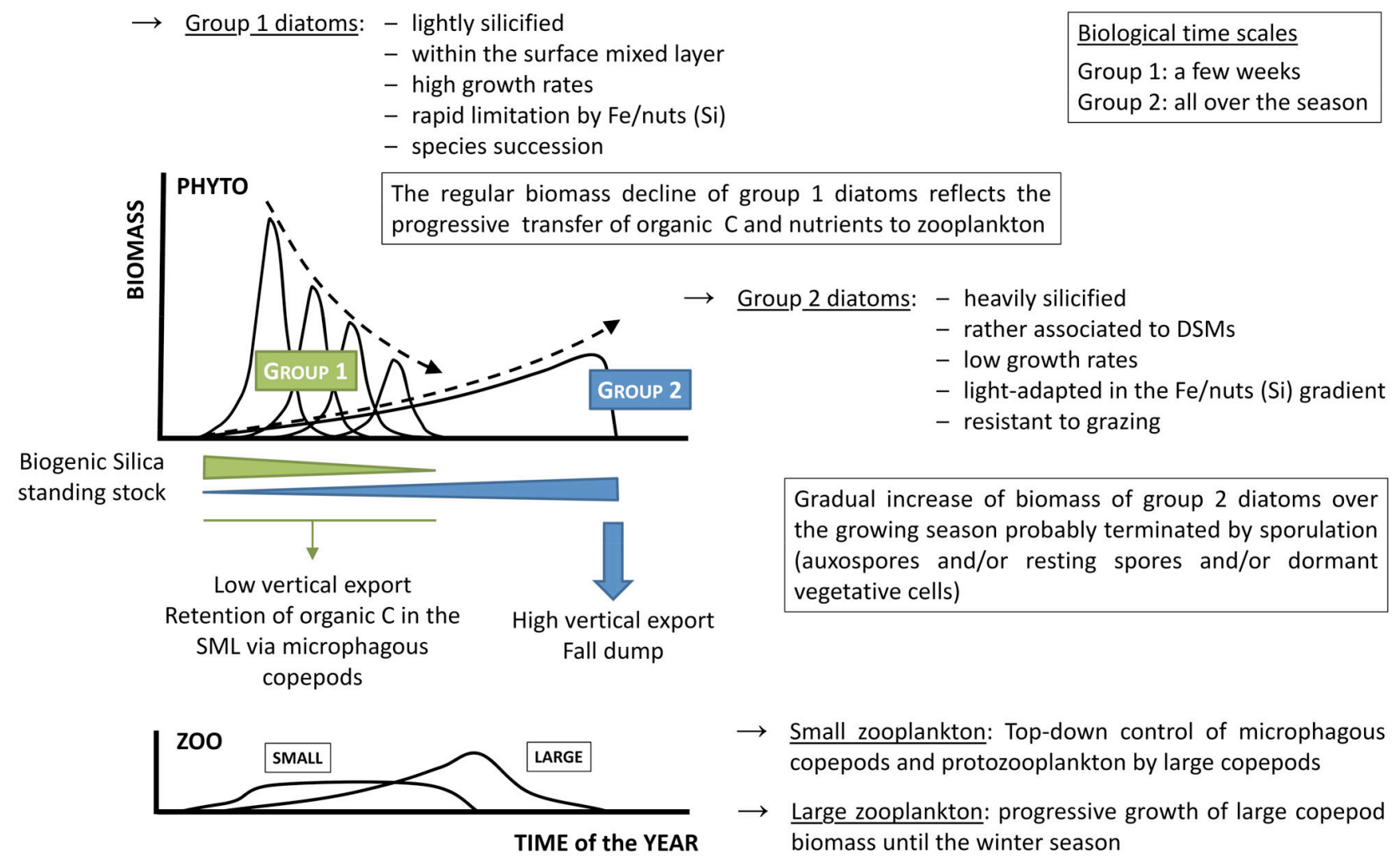

Figure 2: Conceptual scheme of the development of planktonic communities within or at the base of the surface mixed layer (SML) of the Southern Ocean HNLC. On this basic scheme, any further addition of the main limiting factor $(\mathrm{Fe})$ is likely to induce responses of varying magnitude depending on the time at which it takes place (directly related to the amount of major nutrients remaining in the surface layer and not mobilized by zooplankton and higher trophic levels).

\section{Conclusion}

A general conceptual scheme for the development of pelagic ecosystems in the Southern Ocean is developed from the observations made both in artificial fertilization experiments and in those studies dedicated to naturally fertilized systems (Figure 2). A conceptual scheme should only offer a framework for future research: the hypotheses will need to be validated or rejected in future studies. In early spring, the increase in available light allows the development of diatoms at high growth rates, therefore slightly silicified, within the surface mixed layer. These diatom assemblages represent a group that will soon be affected by the availability of nutrients, including iron and silicic acid. Silicic acid will then be gradually eliminated by the operation of the silicon pump. The nutritional control along with the specificities of biological cycles and actions of pathogens cause a succession of dominant species. Succession time windows for each individual species are probably limited to a few weeks. Diatoms can be separated into 2 groups: Group 1 consists of slightly silicified fast growing cells homogeneously distributed in the surface mixed layer, and Group 2 
consists of strongly silicified slowly growing cells within discrete layers. The Group 1 organisms can grow due to the high grazing of small zooplankton on pico- and nanoplankton and protozooplankton, which are primary grazers on diatoms. As the grazing on diatoms from Group 1 appears to be quite low, it is likely that diatom cell death due to nutrient limitation, pathogen action and/or bacterial degradation finally leads to a fragmentation of the organic matter which will then feed the group of omnivorous/detritivorous small zooplankton.

These omnivorous/detritivorous small zooplankton populations may later be consumed gradually by large carnivorous zooplankton, as manifested by a slow increase in large zooplankton biomass during the course of the productive season. In such a system, nutrient recycling and biomass transfer to the more temporally stable compartment of large zooplankton maintain vertical export of nutrients at very low levels. Silicon is the exception, since biogenic silica is unused by zooplankton and therefore is selectively removed by sinking out of the surface mixed layer.

Parallel to the development of diatoms in Group 1, diatoms in Group 2 are located within discrete layers and/or are heterogeneously distributed within the surface layer. They will also be able to develop as the light increases in the spring. Diatoms in this group have lower growth rates and, as a corollary, a strong silicification, which allows them to be very resistant to grazing. The importance of this Group 2 gradually increases as they accumulate biomass throughout the productive period. By gradual accumulation at the pycnocline discontinuity, these organisms benefit indeed from diffusive inputs of nutrients from the upper layer of the mesopelagic zone and gradually build up a deep silica maximum. In this system, the vertical export of organic matter remains low until the late fall and winter. The disappearance of the seasonal pycnocline and intensification of vertical mixing in the late fall and winter then lead to a dispersion of the deep silica maximum and a massive export of organic matter similar to the fall dump, most likely representing the major annual event of the biological pump. The Group 1 diatom community is frequently dominated by Chaetoceros species which are known to produce resting spores at the end of their cell cycle. It remains to be demonstrated that the increase in vertical export of carbon is due to the sedimentation of these Chaetoceros spores (as compared to that of giant diatoms) even if they can act as ballast carrying carbon-rich aggregates. In fact, since the two communities co-exist, albeit at different vertical levels, it is likely that the sedimentation of either of them at the end of their growing seasons, acts as a a filter that moves vertically downward, sweeping almost all organic matter off the epipelagic zone to the deeper water and sediments.

This conceptual scheme will be further refined once we have better identified the discrete levels associated with the different organisms between the surface mixed layer and its base. We also will need a better assessment of the trophic relationships between bacteria, protozooplankton and 
mesozooplankton. These relationships directly affect the regenerative capacity of nitrogen and phosphorus in pelagic systems and the processes that decouple silicon from these major cycles. More attention is needed for biological controlling factors, such as seasonal evolution of diversity of bacteria, flagellates, ciliates and diatoms, in situ growth rates of the dominant species, biological cycles related to endogenous rhythms and roles of pathogens in the future. It is obvious however, that in such a scheme, the artificial addition of a limiting factor is likely to induce very different responses depending on the initial development stage of a system, that explains the differences between observations made in different artificial iron fertilization experiments. Finally, the Southern Ocean offers us a unique case study for understanding the role of iron within a "natural laboratory", and it gives the scientific community an opportunity to glean insight into plankton community processes that probably within most oceanic regions characterized by a seasonal bloom (Blain et al., 2008).

\section{Acknowledgements}

This review was initiated after the workshop 'Modeling and Synthesis of Southern Ocean Natural Iron Fertilization' held at Woods Hole Oceanographic Institution and sponsored by the U.S. National Science Foundation's Office of Polar Programs. The author acknowledges National Science Foundation's Office of Polar Programs for financial support, which enabled his participation to this workshop. The author would also like to thank Matt Charette, Richard Sanders and Meng Zhou for their efforts in conceiving and organizing this productive workshop. Thanks are also due to three anonymous reviewers for their useful comments and to Sarah Gille who kindly helped editing the first manuscript, greatly improving the quality of this paper. Analyses and visualizations used in this paper were produced with the Giovanni online data system, developed and maintained by the NASA GES DISC. This paper is a contribution to the KEOPS program of INSU-CNRS.

\section{References}

Abelmann A., Gersonde R., Cortese G., Kuhn G., Smetacek V., 2006. Extensive phytoplankton blooms in the Atlantic sector of the glacial Southern Ocean. Paleoceanography 21, doi:10.1029/2005PA001199.

Armand L.K., Cornet-Barthaux V., Mosseri J., Quéguiner B., 2008a. Late summer diatom biomass and community structure on and around the naturally iron-fertilised Kerguelen Plateau in the Southern Ocean. Deep-Sea Res. II 55, 653-676.

Armand L.K., Crosta X., Quéguiner B., Mosseri J., Garcia N., 2008b. Diatoms preserved in surface sediments of the northeastern Kerguelen Plateau. Deep-Sea Res. II 55, 677-692.

Assmy P., Ebersbach F., Fuchs N., Klaas C., Montresor M., Smetacek V., 2010. Phyto- and protozooplankton. In: The Expedition of the Research Vessel "Polarstern" to the Antarctic in 
2009 (ANT-XXV/3 - LOHAFEX). Reports on Polar and Marine Research 613, 81-86.

Assmy P., Henjes J., Klaas C., Smetacek V., 2007. Mechanisms determining species dominance in a phytoplankton bloom induced by the iron fertilization experiment EisenEx in the Southern Ocean, Deep-Sea Res. I 54, 340.

Assmy P., Henjes J., Schmidt K., Smetacek V., Montresor M., 2005. The wax and wane of an ironinduced diatom bloom in the Southern Ocean. Reports on Polar and Marine Research 500, 89100.

Atkinson A. 1998. Life cycle strategies of epipelagic copepods in the Southern Ocean. Journal of Marine Systems, 15, 289-311.

Atkinson A., Siegel V., Pakhomov E., Rothery P., 2004. Long-term decline in krill stock and increase in salps within the Southern Ocean. Nature 432, 100.

Bathmann U.V., Scharek R., Klaas C., Dubischar C.D., Smetacek V., 1997. Spring development of phytoplankton biomass and composition in major water masses of the Atlantic sector of the Southern Ocean, Deep-Sea Res. II 44, 51-67.

Bishop J.K.B., Wood T.J., 2009. Year-round observations of carbon biomass and flux variability in the Southern Ocean. Global Biogeochem. Cycles 23, doi:10.1029/2008GB003206.

Blain S., Quéguiner B., Trull T., 2008. The natural iron fertilization experiment KEOPS (KErguelen Ocean and Plateau compared Study): An overview. Deep-Sea Res. II, 55, 559-565.

Blain S., Quéguiner B., Armand L., Belviso S., Bombled B., Bopp L., Bowie A., Brunet C., Brussaard C., Carlotti F., Christaki U., Corbiere A., Durand I., Ebersbach F., Fuda J.L., Garcia N., Gerringa L., Griffiths B., Guigue C., Guillerm C., Jacquet S., Jeandel C., Laan P., Lefèvre D., Lo Monaco C., Malits A., Mosseri J., Obernosterer I., Park Y.H., Picheral M., Pondaven P., Remenyi T., Sandroni V., Sarthou G., Savoye N., Scouarnec L., Souhaut M., Thuiller D., Timmermans K., Trull T., Uitz J., Van Beek P., Veldhuis M., Vincent D., Viollier E., Vong L., Wagener T. 2007. Effect of natural iron fertilization on carbon sequestration in the Southern Ocean. Nature 446, 1070-U1071.

Blain ,S., Tréguer P., Belviso S., Bucciarellia E., Denis M., Desabre S., Fiala M., Martin Jézéquel V., Le Fèvre J., Mayzaud P., Marty J.-C., Razouls S., 2001. A biogeochemical study of the island mass effect in the context of the iron hypothesis: Kerguelen Islands, Southern Ocean. Deep-Sea Res. I 48, 163-187.

Boyd P.W., Abraham E.R., 2001. Iron-mediated changes in phytoplankton photosynthetic competence during SOIREE. Deep-Sea Res. II 48, 2529-2550.

Boyd P.W., Jickells T., Law C.S., Blain S., Boyle E.A., Buesseler K.O., Coale K.H., Cullen J.J., De Baar H.J.W., Follows M., Harvey M., Lancelot C., Levasseur M., Owens N.P.J., Pollard R., 
Rivkin R.B., Sarmiento J., Schoemann V., Smetacek V., Takeda S., Tsuda A., Turner S., Watson A.J., 2007. Mesoscale iron enrichment experiments 1993-2005: Synthesis and future directions. Science 315, 612-617.

Boyd P.W., LaRoche J., Gall M., Frew R. McKay R.M.L., 1999. Role of iron, light, and silicate in controlling algal biomass in subantarctic waters SE of New Zealand. J. Geophys. Res. 104, 13395-13408.

Boyd P.W., Watson A.J., Law C.S., Abraham E.R., Trull T., Murdoch R., Bakker D.C.E., Bowie A.R., Buesseler K.O., Chang H., Charette M., Croot P., Downing K., Frew R., Gall M., Hadfield M., Hall J., Harvey M., Jameson G., La Roche J., Liddicoat M., Ling R., Maldonado M.T., Mckay R.M., Nodder S., Pickmere S., Pridmore R., Rintoul S., Safi K., Sutton P., Strzepek R., Tanneberger K., Turner S., Waite A., Zeldis J., 2000. A mesoscale phytoplankton bloom in the polar Southern Ocean stimulated by iron fertilization. Nature 407, 695-702.

Brzezinski M.A., Pride C.J., Franck V.M., Sigman D.M., Sarmiento J.L., Matsumoto K., Gruber N., Rau G.H. Coale K.H., 2002. A switch from $\mathrm{Si}(\mathrm{OH})_{4}$ to $\mathrm{NO}_{3}^{-}$depletion in the glacial Southern Ocean. Geophys. Res. Letters 29, 10.1029/2001GL014349.

Buesseler K.O., Boyd P.W., 2009. Shedding light on processes that control particle export and flux attenuation in the twilight zone of the open ocean. Limnol. Oceanogr. 54, 1210-1232.

Buesseler K.O., 1998. The decoupling of production and particulate export in the surface ocean. Global Biogeochem. Cycles 12, 297-310.

Calbet A., 2008. The trophic roles of microzooplankton in marine systems. ICES J. Mar. Sci. 65, $325-331$.

Calbet A., Landry M.R., 2004. Phytoplankton growth, microzooplankton grazing, and carbon cycling in marine systems. Limnol. Oceanogr. 49, 51-57.

Carlotti F., Thibault-Botha D., Nowaczyk A., Lefèvre D., 2008. Zooplankton community structure, biomass and role in carbon fluxes during the second half of a phytoplankton bloom in the eastern sector of the Kerguelen Shelf (January-February 2005). Deep-Sea Res. II 55, 720-733.

Cassar N., Difiore P.J., Barnett B.A., Bender M.L., Bowie A.R., Tilbrook B., Petrou K., Westwood K.J., Wright S.W., Lefevre D., 2011. The influence of iron and light on net community production in the Subantarctic and Polar Frontal Zones. Biogeosciences 8, 227-237.

Christaki U., Obernosterer I., Van Wambeke F., Veldhuis M., Garcia N., Catala P., 2008. Microbial food web structure in a naturally iron-fertilized area in the Southern Ocean (Kerguelen Plateau). Deep-Sea Res. II 55, 706-719.

Claquin P., Martin-Jézéquel V., Kromkamp J.C., Veldhuis M.J.W., Kraay G.W., 2002. Uncoupling of silicon compared with carbon and nitrogen metabolisms and the role of the cell cycle in 
continuous cultures of Thalassiosira pseudonana (Bacillariophyceae) under light, nitrogen, and phosphorus control. J. Phycol. 38, 922-930.

Coale K.H., Johnson K.S., Chavez F.P., Buesseler K.O., Barber R.T., Brzezinski M.A., Cochlan W.P., Millero F.J., Falkowski P.G., Bauer J.E., Wanninkhof R.H., Kudela R.M., Altabet M.A., Hales B.E., Takahashi T., Landry M.R., Bidigare R.R., Wang X., Chase Z., Strutton P.G., Friederich G.E., Gorbunov M.Y., Lance V.P., Hilting A.K., Hiscock M.R., Demarest M., Hiscock W.T., Sullivan K.F., Tanner S.J., Gordon R.M., Hunter C.N., Elrod V.A., Fitzwater S.E., Jones J.L., Tozzi S., Koblizek M., Roberts A.E., Herndon J., Brewster J., Ladizinsky N., Smith G., Cooper D., Timothy D., Brown S.L., Selph K.E., Sheridan C.C., Twining B.S., Johnson Z.I., 2004. Southern Ocean Iron Enrichment Experiment: Carbon Cycling in High- and Low-Si Waters. Science 304, 408-414.

Coale K.H., Johnson K.S., Fitzwater S.E., Gordon R.M., Tanner S., Chavez F.P., Ferioli L., Sakamoto C., Rogers P., Millero F., Steinberg P., Nightingale P., Cooper D., Cochlan W.P., Landry M.R., Constantinou J., Rollwagen G., Trasvina A., Kudela R., 1996. A massive phytoplankton bloom induced by an ecosystem-scale iron fertilization experiment in the equatorial Pacific Ocean. Nature 383, 495-501.

de Baar H.J.W., Boyd P.W., Coale K.H., Landry M.R., Tsuda A., Assmy P., Bakker D.C.E., Bozec Y., Barber R.T., Brzezinski M.A., Buesseler K.O., Boyé M., Croot P.L., Gervais F., Gorbunov M.Y., Harrison P.J., Hiscock W.T., Laan P., Lancelot C., Law C.S., Levasseur M., Marchetti A., Millero F.J., Nishioka J., Nojiri Y., Van Oijen T., Riebesell U., Rijkenberg M.J.A., Saito H., Takeda S., Timmermans K.R., Veldhuis M.J.W., Waite A.M., Wong C.-S., 2005. Synthesis of iron fertilization experiments: From the Iron Age in the Age of Enlightenment. J. Geophys. Res. 110, doi:10.1029/2004JC002601.

de Baar H.J.W., Buma A.G.J., Nolting R.F., Cadée G.C., Jacques G., Tréguer P., 1990. On iron limitation of the Southern Ocean : experimental observations in the Weddell and Scotia Seas. Mar. Ecol. Prog. Ser. 65, 105-122.

de Baar H.J.W., De Jong J.T.M., Bakker D.C.E., Löscher B.M., Veth C., Bathmann U., Smetacek V., 1995. Importance of iron for plankton blooms and carbon dioxide drawdown in the Southern Ocean. Nature 373, 412-415.

De Salas M.F., Eriksen R., Davidson A.T., Wright S.W., 2011. Protistan communities in the Australian sector of the Sub-Antarctic Zone during SAZ-Sense. Deep-Sea Res. II 58, 2135-2149.

Drebes G., 1966. On the life history of the marine plankton diatom Stephanopyxis palmeriana. Helgolander Wissenschaften und Meeresuntersuchungen 13, 101-114.

Dubischar C.D., Bathmann U.V., 1997. Grazing impact of copepods and salps on phytoplankton in 
the Atlantic sector of the Southern Ocean. Deep-Sea Res. II, 44, 415-433.

Dubischar C.D., Lopes R.M., Bathmann U.V., 2002. High summer abundances of small pelagic copepods at the Antarctic Polar Front--implications for ecosystem dynamics. Deep-Sea Res. II 49, 3871-3887.

Dugdale R.C., Wilkerson F.P., Minas H.J., 1995. The role of a silicate pump in driving new production. Deep-Sea Res. I 42, 697-719.

Fielding S., Ward P., Pollard R.T., Seeyave S., Read J.F., Hughes J.A., Smith T., Castellani C., 2007. Community structure and grazing impact of mesozooplankton during late spring/early summer 2004/2005 in the vicinity of the Crozet Islands (Southern Ocean). Deep-Sea Res. II 54, 21062125.

Fransz H.G., Gonzalez S.R., 1997. Latitudinal metazoan plankton zones in the Antarctic Circumpolar Current along $6^{\circ} \mathrm{W}$ during austral spring 1992. Deep-Sea Res. II 44, 395-414.

Gall M.P., Boyd P.W., Hall J., Safi K.A., Chang H., 2001. Phytoplankton processes. Part 1: Community structure during the Southern Ocean Iron RElease Experiment (SOIREE). Deep-Sea Res. II 48, 2551-2570.

Gervais F., Riebesell U., Gorbunov M.Y., 2002. Changes in primary productivity and chlorophyll a in response to iron fertilization in the Southern Polar Frontal Zone. Limnol. Oceanogr. 47, 13241335.

Gowing M.M. ,1989. Abundance and feeding ecology of Antarctic phaeodarian radiolarians. Marine Biology 103, 107-118.

Hamm C.E., Merkel R., Springer O., Jurkojc P., Maier C., Prechtel K., Smetacek V., 2003. Architecture and material properties of diatom shells provide effective mechanical protection. Nature 421, 841-843.

Harvey M.J., Law C.S., Smith M.J., Hall J.A., Abraham E.R., Stevens C.L., Hadfield M.G., Ho D.T., Ward B., Archer S.D., Cainey J.M., Currie K.I., Devries D., Ellwood M.J., Hill P., Jones G.B., Katz D., Kuparinen J., Macaskill B., Main W., Marriner A., Mcgregor J., Mcneil C., Minnett P.J., Nodder S.D., Peloquin J., Pickmere S., Pinkerton M.H., Safi K.A., Thompson R., Walkington M., Wright S.W., Ziolkowski L.A., 2011. The SOLAS air-sea gas exchange experiment (SAGE) 2004. Deep-Sea Res. II 58, 753-763.

Henjes J., Assmy P., Klaas C., Smetacek V., 2007a. Response of the larger protozooplankton to an iron-induced phytoplankton bloom in the Polar Frontal Zone of the Southern Ocean (EisenEx). Deep-Sea Res. I 54, 774-791.

Henjes J., Assmy P., Klaas C., Verity P., Smetacek V., 2007b. Response of microzooplankton (protists and small copepods) to an iron-induced phytoplankton bloom in the Southern Ocean 
(EisenEx). Deep-Sea Res. I 54, 363-384.

Hiscock M.R., Lance V.P., Apprill A.M., Bidigare R.R., Johnson Z.I., Mitchell B.G., Smith W.O., Barber R.T., 2008. Photosynthetic maximum quantum yield increases are an essential component of the Southern Ocean phytoplankton response to iron. Proceedings of the National Academy of Sciences of the United States of America. 105, 4775-4780.

Hiscock M.R., Marra J., Smith Jr. W.O., Goericke R., Measures C., Vink S., Olson R.J., Sosik H.M. Barber R.T., 2003. Primary productivity and its regulation in the Pacific Sector of the Southern Ocean. Deep-Sea Res. II 50, 533-558.

Hoffmann L., Peeken I., Lochte K., Assmy P., Veldhuis M., 2006. Different reactions of Southern Ocean phytoplankton size classes to iron fertilization. Limnol. Oceanogr. 51, 1217-1229.

Iversen M.H., Poulsen L.K., 2007. Coprorhexy, coprophagy, and coprochaly in the copepods Calanus helgolandicus, Pseudocalanus elongatus, and Oithona similis. Mar. Ecol. Prog. Ser. 350, 79-89.

Kataoka T., Suzuki K., Hayakawa M., Kudo I., Higashi S., Tsuda A., 2009. Temporal changes in community composition of heterotrophic bacteria during in situ iron enrichment in the western subarctic Pacific (SEEDS-II). Deep-Sea Res. II 56, 2779-2787.

Kemp A.E.S., Pike J., Pearce R.B., Lange C.B., 2000. The "Fall dump" - a new perspective on the role of a "shade flora" in the annual cycle of diatom production and export flux. Deep-Sea Res. II 47, 2129-2154.

Klaas C., 1997. Microprotozooplankton distribution and their potential grazing impact in the Antarctic Circumpolar Current. Deep-Sea Res. II 44, 375-393.

Kleppel G.S., Holliday D.V., Pieper R.E., 1991. Trophic interactions between copepods and microplankton: A question about the role of diatoms. Limnol. Oceanogr. 36, 172-178.

Kopczyńska E.E., Dehairs F., Elskens M., Wright S., 2001. Phytoplankton and microzooplankton variability between the Subtropical and Polar Fronts south of Australia: Thriving under regenerative and new production in late summer. J. Geophys. Res. 106, 31,597-31,609.

Krägefsky S., 2008. On the copepod response to iron-induced phytoplankton blooms in the Southern Ocean. Ph.D. thesis, Universität Bremen, 239 pp.

Kruse S., Jansen S., Krägefsky S., Bathmann U., 2009. Gut content analyses of three dominant Antarctic copepod species during an induced phytoplankton bloom EIFEX (European iron fertilization experiment). Marine Ecology 30, 301-312.

Landry M.R., Selph K.E., Brown S.L., Abbott M.R., Measures C.I., Vink S., Allen C.B., Calbet A., Christensen S., Nolla H., 2002. Seasonal dynamics of phytoplankton in the Antarctic Polar Front 
region at $170^{\circ} \mathrm{W}$. Deep-Sea Res. II 49, 1843-1865.

Leblanc K., Hare C.E., Boyd P.W., Bruland K.W., Sohst B., Pickmere S., Lohan M.C., Buck K., Ellwood M., Hutchins D.A., 2005. Fe and Zn effects on the Si cycle and diatom community structure in two contrasting high and low-silicate HNLC areas. Deep-Sea Res. I 52, 1842-1864

Lucas M., Seeyave S., Sanders R., Moore M.C., Williamson R., Stinchcombe M., 2007. Nitrogen uptake responses to a naturally Fe-fertilised phytoplankton bloom during the 2004/2005 CROZEX study. Deep-Sea Res. II 54, 2138.

Marchetti A., Sherry N.D., Kiyosawa H., Tsuda A., Harrison P.J., 2006. Phytoplankton processes during a mesoscale iron enrichment in the NE subarctic Pacific: Part I - Biomass and assemblage, Deep-Sea Res. II 53, 2095-2113.

Margalef R., 1978. Life-forms of phytoplankton as survival alternatives in an unstable environment. Oceanologica Acta, 1, 493-509.

Martin J.H., Fitzwater S.E., 1990. Iron deficiency limits phytoplankton growth in Antarctic waters. Global Biogeochem. Cycles 4, 5-12.

Martin J.H., Coale K.H., Johnson K.S., Fitzwater S.E., Gordon R.M., Tanner S.J., Hunter C.N., Elrod V.A., Nowicki J.L., Coley T.L., Barber R.T., Lindley S., Watson A.J., Van Scoy K., Law C.S., Liddicoat M.I., Ling R., Stanton T., Stockel J., Collins C., Anderson A., Bidigare R., Ondrusek M., Latasa M., Millero F.J., Lee K., Yao W., Zhang J.Z., Friederich G., Sakamoto C., Chavez F., Buck K., Kolber Z., Greene R., Falkowski P., Chisholm S.W., Hoge F., Swift R., Yungel J., Turner S., Nightingale P., Hatton A., Liss P., Tindale N.W., 1994. Testing the iron hypothesis in ecosystems of the equatorial Pacific Ocean. Nature 371, 123-129.

Matsumoto K., Sarmiento J.L., Brzezinski M.A., 2002. Silicic acid leakage from the Southern Ocean: A possible explanation for glacial atmospheric $\mathrm{pCO}_{2}$. Global Biogeochem. Cycles 16, doi:10.1029/2001GB001442.

Mayzaud P., Tirelli V., Errhif A., Labat J.-P., Razouls S., Perissinotto R., 2002. Carbon intake by zooplankton. Importance and role of zooplankton grazing in the Indian sector of the Southern Ocean. Deep-Sea Res. II 49, 3169-3187.

Mazzocchi M.G., González H.E., Borrione I., Vandromme P., Ribera d'Alcalà M., 2010. Meso- and macro-zooplankton. In: The Expedition of the Research Vessel "Polarstern" to the Antarctic in 2009 (ANT-XXV/3 - LOHAFEX). Reports on Polar and Marine Research 613, 87-92.

Mitchell B.G., Holm-Hansen O., 1991. Observations and modeling of the Antarctic phytoplankton crop in relation to mixing depth. Deep-Sea Res. I 38, 981-107.

Mitchell B.G., Brody E.A., Holm-Hansen O., Mcclain C., Bishop J., 1991. Light limitation of phytoplankton biomass and macronutrient utilization in the Southern Ocean. Limnol. Oceanogr. 
$36,1662-1677$.

Moore C.M, Seeyave S., Hickman A.E., Allen J.T., Lucas M.I., Planquette H., Pollard R.T. Poulton A.J., 2007. Iron-light interactions during the CROZet natural iron bloom and EXport experiment (CROZEX) I: Phytoplankton growth and photophysiology. Deep-Sea Res. II 54, 2045.

Mosseri J., Quéguiner B., Armand L.K., Cornet-Barthaux V., 2008. Impact of iron on silicon utilization by diatoms in the Southern Ocean: A case study of $\mathrm{Si} / \mathrm{N}$ cycle decoupling in a naturally iron-enriched area. Deep-Sea Res. II 55, 801.

Nakamura Y., Turner J.T. 1997. Predation and respiration by the small cyclopoid copepod Oithona similis: How important is feeding on ciliates and heterotrophic flagellates? J. Plankt. Res. 19, 1275-1288.

Nelson D.M., Smith Jr W.O., 1991. Sverdrup revisited: critical depths, maximum chlorophyll levels, and the control of Southern Ocean productivity by the irradiance-mixing regime. Limnol. Oceanogr. 36, 1650-1661.

Nelson D.M., Brzezinski M.A., Sigmon D.E., Franck V.M., 2001. A seasonal progression of Si limitation in the Pacific sector of the Southern Ocean. Deep-Sea Res. II 48, 3973-3995.

Obernosterer I., Christaki U., Lefèvre D., Catala P., Van Wambeke F., Lebaron P., 2008. Rapid bacterial mineralization of organic carbon produced during a phytoplankton bloom induced by natural iron fertilization in the Southern Ocean. Deep-Sea Res. II 55, 777-789.

Olson R.J., Sosik H.M., Chekalyuk A.M., Shalapyonok A., 2000. Effects of iron enrichment on phytoplankton in the Southern Ocean during late summer: active fluorescence and flow cytometric analyses. Deep-Sea Res. II 47, 3181-3200.

Pakhomov E.A., Froneman P.W., Perissinotto R., 2002. Salp/krill interactions in the Southern Ocean: spatial segregation and implications for the carbon flux. Deep-Sea Res. II 49, 1881-1907.

Pasternak A., Hagen W., Kattner G., Michels J., Graeve M., Schnack-Schiel S.B., 2009. Lipid dynamics and feeding of dominant Antarctic calanoid copepods in the eastern Weddell Sea in December. Polar Biol. 32, 1597-1606.

Pasternak A.F., Schnack-Schiel S.B., 2001. Feeding patterns of dominant Antarctic copepods: an interplay of diapause, selectivity, and availability of food. Hydrobiologia 453-454, 25-36.

Peloquin J.A., Smith Jr W.O., 2007. Phytoplankton blooms in the Ross Sea, Antarctica: Interannual variability in magnitude, temporal patterns, and composition. J. Geophys. Res. 112, doi:10.1029/2006JC003816.

Peloquin J., Hall J., Safi K., Ellwood M., Law C.S., Thompson K., Kuparinen J., Harvey M., Pickmere S., 2011. Control of the phytoplankton response during the SAGE experiment: A 
synthesis. Deep-Sea Res. II 58, 824-838.

Pollard R.T., Bathmann U., Dubischar C., Read J.F., Lucas M., 2002. Zooplankton distribution and behaviour in the Southern Ocean from surveys with a towed Optical Plankton Counter. Deep-Sea Res. II 49, 3889-3915.

Pollard R.T., Salter I., Sanders R.J., Lucas M.I., Moore C.M., Mills R.A., Statham P.J., Allen J.T., Baker Al.R., Bakker D.C.E., Charette M.A., Fielding S., Fones G.R., French M., Hickman A.E., Holland R. J., Hughes J.A., Jickells T.D., Lampitt R.S., Morris P.J., Nédélec F.H., Nielsdottir M., Planquette H., Popova E.E., Poulton A.J., Read J.F., Seeyave S., Smith T., Stinchcombe M., Taylor S., Thomalla S., Venables H.J., Williamson R., Zubkov M.V., 2009. Southern Ocean deepwater carbon export enhanced by natural iron fertilization. Nature 457, 577-580.

Pond D.W., Ward P., 2011. Importance of diatoms for Oithona in Antarctic waters. J. Plankt. Res. $33,105-118$.

Poulton A.J, Moore M.C., Seeyave S., Lucas M.I., Fielding S., Ward P., 2007. Phytoplankton community composition around the Crozet Plateau, with emphasis on diatoms and Phaeocystis. Deep-Sea Res. II 54, 2085-2105.

Quéguiner B., 2001. Biogenic silica production in the Australian sector of the Subantarctic Zone of the Southern Ocean in late summer 1998. J. Geophys. Res. 106, 31627-31636.

Quéguiner B., Blain S., Trull T., 2011. High primary production and vertical export of carbon over the Kerguelen Plateau as a consequence of natural iron, in: Duhamel G., Welsford D. (Eds.), The Kerguelen Plateau: marine ecosystem and fisheries, Proceedings of the $1^{\text {st }}$ international Science Symposium on the Kerguelen Plateau. Société Française d'Ichtyologie, Parsi, pp. 169-174.

Quéguiner B., Tréguer P., Peeken I., Scharek R., 1997. Biogeochemical dynamics and the silicon cycle in the Atlantic sector of the Southern Ocean during austral spring 1992. Deep-Sea Res. II 44, 69-89.

Robinson C., Steinberg D.K., Anderson T.R., Arístegui J., Carlson C.A., Frost J.R., Ghiglione J.-F., Hernández-León S., Jackson G.A., Koppelmann R., Quéguiner B., Ragueneau O., Rassoulzadegan F., Robison B.H., Tamburini C., Tanaka T., Wishner K.F., Zhang J., 2010. Mesopelagic ecology and biogeochemistry - a synthesis. Deep-Sea Res. II 57, 1504-1518.

Rutgers Van Der Loeff M.M., Buesseler K., Bathmann U., Hense I., Andrews J., 2002. Comparison of carbon and opal export rates between summer and spring bloom periods in the region of the Antarctic Polar Front, SE Atlantic. Deep-Sea Res. II 49, 3849-3869.

Rutgers Van Der Loeff M.M., Friedrich J., Bathmann U.V., 1997. Carbon export during the spring bloom at the Antarctic Polar Front, determined with the natural tracer ${ }^{234}$ Th. Deep-Sea Res. II 44, 457-478. 
Saito H., Tsuda A., Nojiri Y., Nishioka J., Takeda S., Kiyosawa H., Kudo I., Noiri Y., Ono T., Taira Y., 2006. Nutrient and phytoplankton dynamics during the stationary and declining phases of a phytoplankton bloom induced by iron-enrichment in the eastern subarctic Pacific. Deep-Sea Res. II $53,2168-2181$

Saito H., 2006. Zooplankton responses during SEEDS. Report of the 2004 Workshop on In Situ Iron Enrichment Experiments in the Eastern and Western Subarctic Pacific, February 11-13, 2004, Victoria, British Columbia, Canada, PICES Scientific Report N 31, pp. 19-21.

Saiz E., Calbet A., 2011. Copepod feeding in the ocean: scaling patterns, composition of their diet and the bias of estimates due to microzooplankton grazing during incubations. Hydrobiologia 666, 181-196.

Salter I., Kemp A.E.S., Moore C.M., Lampitt R.S., Wolff G.A., Holtvoeth J., 2012. Diatom resting spore ecology drives enhanced carbon 1 export from a naturally iron fertilized bloom in the Southern Ocean. Global Biogeochem. Cycles 26, doi:10.1029/2010GB003977.

Salter I., Lampitt R.S., Sanders R., Poulton A., Kemp A.E.S., Boorman B., Saw K., Pearce R., 2007. Estimating carbon, silica and diatom export from a naturally fertilised phytoplankton bloom in the Southern Ocean using PELAGRA: A novel drifting sediment trap. Deep-Sea Res. II 54, 22332259.

Sanders R., Morris P.J., Stinchcombe M., Seeyave S., Venables H., Lucas M., 2007. New production and the f ratio around the Crozet Plateau in austral summer 2004-2005 diagnosed from seasonal changes in inorganic nutrient levels. Deep-Sea Res. II 54, 2191.

Sarmiento J.L., Dunne J., Armstrong R.A., 2004. Do We Now Understand The Ocean's Biological Pump? U.S. JGOFS Newsletter 12, 1-5.

Schultes S., Verity P.G., Bathmann U., 2006. Copepod grazing during an iron-induced diatom bloom in the Antarctic Circumpolar Current (EisenEx): I. Feeding patterns and grazing impact on prey populations. J. Exp. Mar. Biol. Ecol. 338, 16-34.

Seeyave S., Lucas M.I., Moore C.M., Poulton A.J., 2007. Phytoplankton productivity and community structure in the vicinity of the Crozet Plateau during austral summer 2004/2005. Deep-Sea Res. II 54, 2020-2044.

Sherr E.B., Sherr B.F., 2007. Heterotrophic dinoflagellates: a significant component of microzooplankton biomass and major grazers of diatoms in the sea. Mar. Ecol. Prog. Ser. 352, 187-197.

Smetacek V., 2001. EisenEx. International team conducts iron experiment in the Southern Ocean. U.S. JGOFS Newsletter 11, 11-14.

Smetacek V., 2005. The expeditions ANTARKTIS XXI/3-4-5 of the research vessel "Polarstern" in 
2004 / [Alfred-Wegener-Institut für Polar- und Meeresforschung] / U. Bathmann and E. Helmke (editors), Berichte zur Polar- und Meeresforschung (Reports on Polar and Marine Research), Bremerhaven, Alfred Wegener Institute for Polar and Marine Research, 500 , 302 pp., ISSN: 1618-3193 .

Smetacek V., Naqvi S.W.A., 2008. The next generation of iron fertilization experiments in the Southern Ocean. Phil. Trans. R. Soc. A 366, 3947-3967.

Smetacek V., De Baar H.J.W., Bathmann U.V., Lochte K., Rutgers Van Der Loeff M.M., 1997. Ecology and biogeochemistry of the Antarctic Circumpolar Current during austral spring: A summary of Southern Ocean JGOFS cruise ANT X/6 of R.V. Polarstern. Deep-Sea Res.II 44, 121.

Smetacek V., Klaas C., Menden-Deuer S., and Rynearson T.A., 2002. Mesoscale distribution of dominant diatom species relative to the hydrographical field along the Antarctic Polar Front. Deep-Sea Res. II 49, 3835-3848.

Smetacek V., 2010. The expedition of the research vessel "Polarstern" to the Antarctic in 2009 (ANT-XXV/3 - LOHAFEX) / V. Smetacek and S. Naqvi (editors), Berichte zur Polar- und Meeresforschung (Reports on Polar and Marine Research), Bremerhaven, Alfred Wegener Institute for Polar and Marine Research, 613 , 113 pp., ISSN: 1866-3192 .

Sosik H.M., Olson R.J., 2002. Phytoplankton and iron limitation of photosynthetic efficiency in the Southern Ocean during late summer. Deep-Sea Res. I, 49, 1195-1216.

Sournia A., 1982. Is there a shade flora in the marine plankton? J. Plankt. Res., 4, 391-400.

Strass V.H., Bathmann U.V., Rutgers Van Der Loeff M.M., Smetacek V., 2002a. Mesoscale physics, biogeochemistry and ecology of the Antarctic Polar Front, Atlantic sector: an introduction to and summary of cruise ANT XIII/2 of R.V. Polarstern. Deep-Sea Res. II 49, 3707-3711.

Strass V.H., Naveira Garabato A.C., Pollard R.T., Fischer H.I., Hense I., Allen J.T., Read J.F., Leach H., Smetacek V., 2002b. Mesoscale frontal dynamics: shaping the environment of primary production in the Antarctic Circumpolar Current. Deep-Sea Res. II 49, 3735-3769.

Suzuki K., Saito H., Isada T., Hattori-Saito A., Kiyosawa H., Nishioka J., Mckay R.M.L., Kuwata A., Tsuda A., 2009. Community structure and photosynthetic physiology of phytoplankton in the northwest subarctic Pacific during an in situ iron fertilization experiment (SEEDS-II), Deep-Sea Res. II 56, 2733-2744.

Svensen C., Seuthe L., Vasilyeva Y., Pasternak A., Hansen E., 2011. Zooplankton distribution across Fram Strait in autumn: Are small copepods and protozooplankton important? Progress Oceanogr. 91, 534-544.

Takahashi K.T., Hosie G.W., Kitchener J.A., Mcleod D.J., Odate T., Fukuchi M., 2010. Comparison 
of zooplankton distribution patterns between four seasons in the Indian Ocean sector of the Southern Ocean. Polar Sci. 4, 317-331.

Tremblay J.E., Lucas M.I., Kattner G., Pollard R., Strass V.H., Bathmann U., Bracher A., 2002. Significance of the Polar Frontal Zone for large-sized diatoms and new production during summer in the Atlantic sector of the Southern Ocean. Deep-Sea Res. II 49, 3793-3811.

Tsuda A., Kiyosawa H., Kuwata A., Mochizuki M., Shiga N., Saito H., Chiba S., Imai K., Nishioka J., Ono T., 2005. Responses of diatoms to iron-enrichment (SEEDS) in the western subarctic Pacific, temporal and spatial comparisons, Progress Oceanogr. 64, 189-205.

Tsuda A., Saito H., Machida R.J., Shimode S., 2009. Meso- and microzooplankton responses to an in situ iron fertilization experiment (SEEDS II) in the northwest subarctic Pacific. Deep-Sea Res. II $56,2767-2778$.

Tsuda A., Takeda S., Saito H., Nishioka J., Nojiri Y., Kudo I., Kiyosawa H., Shiomoto A., Imai K., Ono T., Shimamoto A., Tsumune D., Yoshimura T., Aono T., Hinuma A., Kinugasa M., Suzuki K., Sohrin Y., Noiri Y., Tani H., Deguchi Y., Tsurushima N., Ogawa H., Fukami K., Kuma K., Saino T., 2003. A mesoscale iron enrichment in the western subarctic Pacific induces a large centric diatom bloom. Science 300, 958-961.

Venables H., Moore C.M., 2010. Phytoplankton and light limitation in the Southern Ocean: Learning from high-nutrient, high-chlorophyll areas. J. Geophys. Res. 115, C02015.

Venables H.J., Pollard R.T., Popova E.E.2007. Physical conditions controlling the development of a regular phytoplankton bloom north of the Crozet Plateau, Southern Ocean. Deep-Sea Res. II 54, 1949-1965.

Waite A.M., Nodder S.D., 2001. The effect of in situ iron addition on the sinking rates and export flux of Southern Ocean diatoms, Deep Sea Research Part II 48, 2635-2654.

Wilken S., Hoffmann B., Hersch N., Kirchgessner N., Dieluweit S., Rubner W., Hoffmann L.J., Merkel R., Peeken I., 2011. Diatom frustules show increased mechanical strength and altered valve morphology under iron limitation. Limnol. Oceanogr. 56, 1399-1410.

Zeldis J., 2001. Mesozooplankton community composition, feeding, and export production during SOIREE. Deep-Sea Res. II 48, 2615-2634. 